\title{
Intensifiers in Bidayuh Bau-Jagoi
}

\author{
Yvonne Michelle Campbell*1 \\ Jill Beon ${ }^{2}$ \\ Su-Hie Ting ${ }^{3}$ \\ ${ }^{1,2,3}$ Faculty of Language and Communication, Universiti Malaysia Sarawak \\ 1mvyvonne@unimas.my \\ 2janejill63@gmail.com \\ 3shting@unimas.my
}

Manuscript received 19 February 2020

Manuscript accepted 3 June 2020

*Corresponding author

https://doi.org/10.33736/ils.2292.2020

\begin{abstract}
This paper describes intensifiers in Bidayuh Bau-Jagoi, a variation of the Bidayuh language, spoken in Sarawak, Malaysia. Data were gathered from 10 informants, aged 50-80, who are native speakers of the Bidayuh Bau-Jagoi. In this language, intensifiers are used to intensify the meaning of expressions, particularly adjectives. Results show that intensifiers are categorised into lexical items and reduplication. Three general lexical items (sikia, manah and bonar) were identified from the data, and 86 specific lexical intensifiers were found to be paired with specific adjectives with the exception of posah and ngakag. There is only one full reduplication form where a lexical item is reduplicated (tok-tok) and it intensifies the meaning of the adjectives that precede it. As for lexical items, the intensifiers are placed after the adjective with the exception of sikia. This study has uncovered rules pertaining to the use of intensifiers in Bidayuh Bau-Jagoi that will lead to a proper and better understanding of the language structure.
\end{abstract}

Keywords: adjectives, Bidayuh Bau-Jagoi, intensifiers, reduplication

\section{Introduction}

Studies on intensifiers have been conducted as early as the 1900, for example, "very", "really", "bloody", "rather" and "somewhat" (Bolinger, 1972; Fries, 1940; Quirk, Greenbaum, Leech, \& Svartvik, 1985; Stoffle, 1901; Wittouck, 2011). Much of the research has been on English, thereby enabling the structural and functional features of English intensifiers to be better understood. For example, English intensifiers are expressed in one word and is placed before an adjective (Paradis, 2008; Stoffel, 1901). Paradis (2008) has developed a categorisation of intensifiers based on the degree of "boundedness". Intensifiers can be either pre-head or posthead modifier, or combination of both like in the Malay language (Ahmad \& Jalaluddin, 2012). Similarly, Papuan Malay also exhibits the same structure. Most of 
the adverbs occur in pre-predicate position except sekali (very), which takes a postpredicate position (Kluge, 2017).

Intensifiers are often referred to as degree adverbs (Bolinger, 1972; Quirk et al., 1985). Intensifiers represent the emotional aspect in thought conventions among humans. According to Bolinger (1972), "human fondness of exaggeration" has produced a variation of dramatic word choice to convey thoughts and feelings. Generally, intensifiers are found in natural languages as means to express a scale of "bigness" or "smallness" of adjectives in order to create an impression of intensity. In linguistics, an adjective is a descriptive word, the main syntactic role of which is to qualify a noun or noun phrase, giving more information about the object signified. Intensifiers are a type of expressive language that helps speakers to convey the scale of adverbial intensity to the listeners (e.g., "a little hot", "too hot"). Intensifiers add more emotional content to their utterance, so that speakers can convey more than just referential meaning (Holmes, 2006).

Apart from that, intensifiers can exist as just one word with independent functions and meanings. In the Siquijodnon-Cebuano language of the Philippines, intensifiers consist of one word which functions independently or in isolation as qualifier or intensifier of an adjective or a quality pronoun (Bantawig \& Marano, 2017). In Banyumas Dialect, intensifiers were analysed and realised as lexical items and reduplication, with general as well as specific functions attached to certain adjectives (Hadiati, 2017).

While the documentation of intensifiers in the West had been done as early as the 1900, realisation of intensifiers in Austronesian language is still lacking. Recently, the advent of the internet facilitated corpus-based studies, and this has allowed more comparative studies on different semantic aspect or different languages (Su, 2016). However, few studies have been conducted on intensifiers in Austronesian languages. For the Bidayuh Bau-Jagoi variety spoken by Bidayuh people in specific parts of Sarawak, Malaysia, the earliest mention of intensifier in descriptions of the Bidayuh language was by Rensch, Rensch, Noeb and Ridu (2012) but there was no elaboration. Rensch et al. (2012) focused on the phonology, morphology and, to a certain extent, the syntax of the language. They reported that Bau-Jagoi and Singai have special intensifier words, unique for each adjective, that have lost all their independent meaning. Apart from this mention, no further information was provided on the form and categories of intensifiers. It was only recently that Bongarrá and Tan (2017) explained the characteristics of adjectives in two variations of Bidayuh language, which is the Bukar-Sadong and Bau-Bidayuh. They described Bau-Bidayuh adjectives/stative verbs as consisting of reduplication and compounding which function to intensify the meaning but did not examine the intensity of the intensifiers. Bongarrá and Tan (2017) refer to intensifiers as adjectival compounding.

In order to learn and understand the Bidayuh language, it is important for non-native speakers to learn these rules involving intensifiers and their use with adjectives. This is because the position and pairing of different intensifiers with different adjectives is rule-governed and documentation of this will lead to a proper understanding of the grammar and syntax of the Bidayuh Bau-Jagoi language. 
This paper describes the types and categories of intensifiers in the Bidayuh Bau-Jagoi variety. In this paper, we show that intensifiers that fall into the category of general lexical items and full reduplication are words that are used before almost any adjective, while specific lexical items are those that go with certain adjectives. These specific lexical item intensifiers are low frequency intensifiers which may not be passed on to the next generation because they are more difficult for the younger generation and new speakers of Bau-Jagoi to learn. We will describe the Bidayuh Bau-Jagoi language and adjectives in Bidayuh, followed by a report on findings on intensifiers in Bidayuh. In addition, a description of intensifiers in Bidayuh Bau-Jagoi using Bickel, Comrie, and Haspelmath's (2015) Leipzig Glossing Rules is also provided. This is a convention for interlinear morpheme-by-morpheme glosses.

\section{Background}

\section{Bidayuh Bau-Jagoi}

The Bidayuh is one of the indigenous native groups of Sarawak, Malaysia. Totalling at 210,000 people, they are the fourth largest ethnic group of Sarawak (Chang, 2002). The Bidayuh are divided into six main groups which are Bau, Biatah, Serian, Tringgus-Sembaan, Salako and Rara (Rencsh et al., 2012). The different Bidayuh groups speak different varieties.

This paper uses the Bidayuh Bau spelling (Dayak Bidayuh National Association, 2013) and the variety is referred to as Bidayuh Bau-Jagoi in the rest of this paper. At the present time, the Bidayuh Bau-Jagoi is mainly used among Bidayuh who speak the same variety in urban areas but it is still extensively used in the villages located in the Bau-Jagoi area. There is a section for Bidayuh Bau-Jagoi in the national radio station Wai.fm which is a three-hour segment, Ngarom Pawun.

\section{Adjectives and intensifiers in Austronesian languages}

Adjectives are "words that belong to a class whose members modify nouns, specifying the properties or attributes of a noun referent" (Crystal, 1991, p. 108, as cited in Bongarrá \& Tan, 2017). Bongarrá and Tan (2017) pointed out that simply labelling these words as" adjectives" is not sufficient. They also claimed that in Bidayuh, the division between adjectives and stative verb is not clear.

Bongarrá and Tan (2017) stated two syntactic functions of adjectives in Bidayuh, that is, to modify nouns and to serve as predicates. In modifying nouns, adjectives may appear before or after head nouns or even both. Besides that, when adjectives are modified by quantifiers, degree words or another adjective, they form adjective phrases. As predicates, adjectives take the place of a verb phrase. Bongarrá and Tan (2017, p. 110) refers to these adjectives as "stative verbs".

The term "intensifier" is often used interchangeably with terms like "degree adverbs" or "degree modifiers" (Su, 2016). Intensifiers exist to support adjectives and to give adjectives a measurement of intensity. Intensifiers are lexical items in the form of free morphemes. In English for instance, intensifiers such as "very" and "so" are used before an adjective to intensify the meaning. Intensifiers in 
Siquijodnon (spoken in the Philippines) which carry the meaning of "so" and "very" are kayo, baling, perte/perting and grabi/grabing and can be used with any adjective (Bantawig \& Marano, 2017).

Hadiati (2017) found that intensifiers in the Banyumas dialect in Indonesia are realised into lexical items and reduplication, based on an analysis of natural conversations using the Leipzig Glossing Rule (Bickel et al., 2015). Her results also showed that lexical items can be further classified into general intensifiers (free intensifiers which are found after adjectives and rarely in front of adjectives) and specific intensifiers restricted to certain adjectives. Banyumas intensifier in the category of reduplication is divided into full and partial reduplication. For example, full reduplication of an intensifier is used specifically to intensify the colour of green (royo-royo) and the height of a kite (laur-laur). Hadiati (2017) further stated that reduplication with vowel change undertakes grammaticalisation because lexical items which are used in this reduplication form lose their semantic content.

The Malay and Tamil languages have a number of partial reduplication (Nadarajan, 2006). Malay uses partial reduplication to show plurality of nouns (murid-murid means many students) and intensity of adjectives (Tarik kuat-kuat means pull very strongly). While at the outset it might appear that Malay and Tamil languages have a more widespread role for reduplication and repetition in their daily discourse, corpus-based studies on reduplication and repetition in English has revealed the situation to be otherwise.

\section{Method}

The description of intensifiers on Bidayuh Bau-Jagoi is based on data collected from 10 informants, aged 50-80, who are native speakers of the Bidayuh Bau-Jagoi language. The informants lived in seven villages in the Bau-Jagoi area and have good knowledge and proficiency in Bidayuh Bau-Jagoi language.

The informants were given a list of adjectives in Malay and were asked to translate them into Bidayuh Bau-Jagoi. Then they were asked to produce intensifiers by giving example of sentences in Malay. The list comprised 115 adjectives from nine domains (Karim, Onn, Musa, \& Mahmood, 2015), which are quality/situation, colour, measurement, shape, time, distance, action, emotion and sensory. Informants were encouraged to produce intensifiers in many levels of intensity and reduplications.

For the purpose of reporting the results, the intensifiers were translated into English and presented on word-by-word level according to the Leipzig Glossing Rules (Bickel et al., 2015). Using Rule 1, interlinear glosses were aligned vertically, word by word, with the example. Next, intensifiers were categorised into lexical items (with general and specific functions) and reduplication based on Hadiati (2017). Finally, the intensifiers were categorised based on their intensity into maximizer and booster. 


\section{Results and Discussion}

\section{Categorisation of Intensifiers}

This section describes the categorisation of intensifiers in Bidayuh Bau-Jagoi language based on Hadiati (2017). The data analysis showed that Bidayuh Bau-Jagoi intensifiers are realised as lexical items and reduplication (Figure 1).

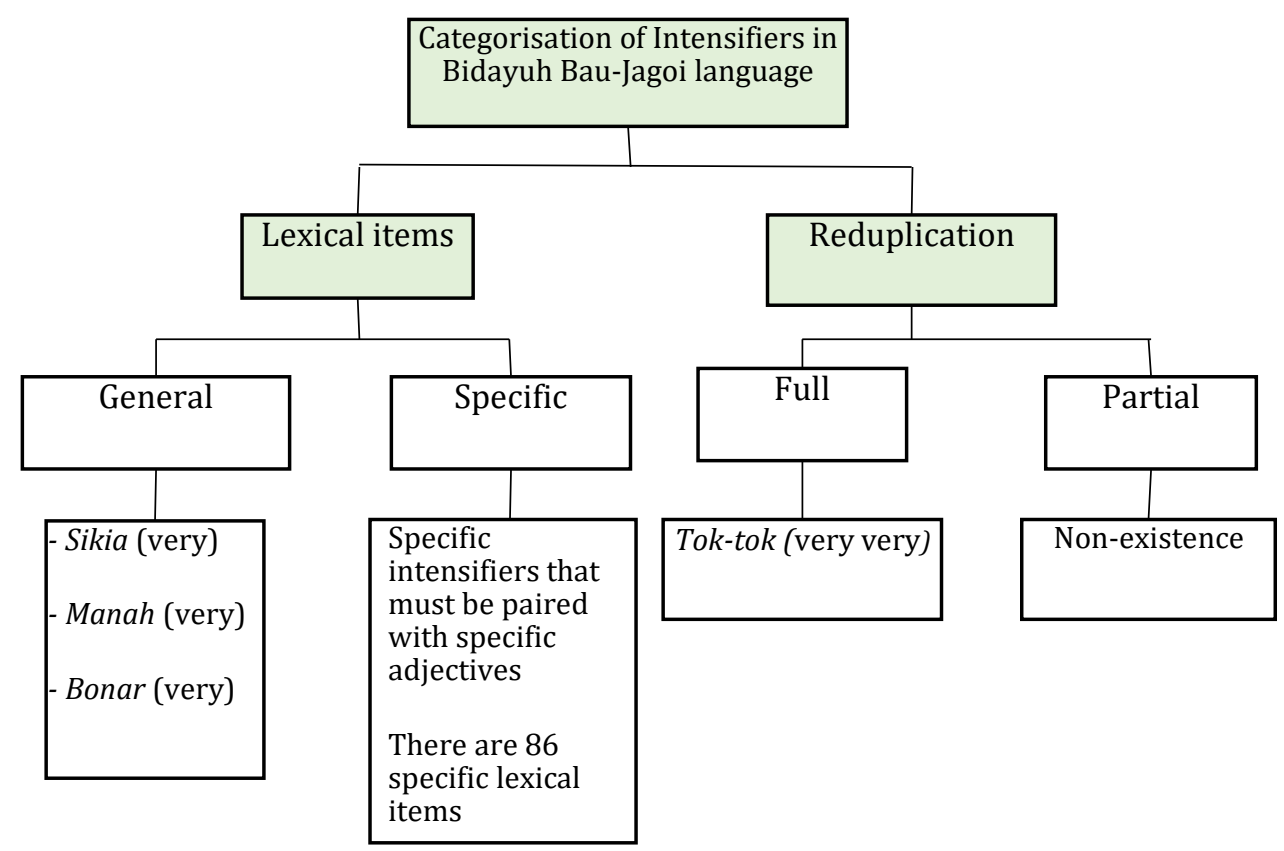

Figure 1. Categorization of intensifiers in Bidayuh Bau-Jagoi language

\section{Lexical items.}

Lexical items include one-word intensifiers that intensify the meaning of adjectives, and are subdivided into general and specific lexical items (Hadiati, 2017). Based on the data, both general and specific lexical item intensifiers are found in Bidayuh BauJagoi. Three general lexical items were found, namely, sikia, manah and bonar, all carrying the meaning of "very" and can be paired with nearly any adjective. They differ in term of their position either before or after the adjective they describe. For example, sikia jaat (very bad), jaat bonar (bad very) and jaat manah (bad very). Sikia is placed in front of an adjective while bonar and manah are placed after the adjective (See further examples in Appendix 1). This is syntactic knowledge that only native speakers of Bidayuh Bau-Jagoi have.

Next, the data showed that the Bidayuh Bau-Jagoi language has specific lexical items intensifiers that must be paired with certain adjectives, and they are always placed after the adjectives. For example, sidik broma which means "utterly delicious". Specific lexical items also have another interesting characteristic in that they do not have any semantic meaning on their own. These lexical items are only 
present on the grammatical level, which is to support their specific adjectives to create maximum intensity. Table 1 shows adjectives and its specific intensifiers in Domain 9(a) of Taste. For the other pairing of specific intensifiers and adjectives in the other eight domains, see the Appendix 1.

Table 1

Adjectives and its specific Intensifiers in Domain 9(a) Taste

\begin{tabular}{lll}
\hline & Adjective & \multicolumn{1}{c}{ Intensifiers } \\
\hline 1. delicious & sidik & bromak \\
2. salty & pidie' & ngakag \\
3. bitter & po'it & Podiel \\
4. sour & masuom & kiduduom \\
5. spicy & poras & ngakag \\
\hline
\end{tabular}

\section{Reduplication.}

The other category of intensifier is reduplication. Stewart and Vaillette (2001) explained reduplication as a process of forming new words either by doubling an entire free morpheme (total reduplication) or part of it (partial reduplication). In Banyumas dialect, reduplications exist in both full and partial reduplication to express intensity (Hadiati, 2017) but in Bidayuh Bau-Jagoi there is no partial reduplication.

Only full reduplication is found in Bidayuh Bau-Jagoiin two forms. The first form of full reduplication is an intensifier tok-tok, literally translated as "very-very". On its own, tok means "true". The phrase tok-tok po'it means "very, very bitter".

The second form of full reduplication in Bidayuh Bau-Jaoi is reduplication of the adjectives. Once the adjectives are reduplicated, the meaning is intensified. In this study, the informants provided only four intensifiers shown in Examples (1)-(4).

(1) Sab-sab Gloomy-gloomy

Today is so/very gloomy.

(2) Banam-banam Gloomy-gloomy This morning is so/very gloomy.

(3) Sorut-sorut Weak-weak $\mathrm{He}$ is so/very weak.

(4) Suom-suom Early-early Woke up so/very early.

$\begin{array}{ll}\text { onu } & \text { tih. } \\ \text { day } & \text { this. }\end{array}$

pagi tih.

morning this.

turang eh.

bone his.

mokat bo'os.

wake up sleep. 
In Example (1), the reduplication of sab-sab (gloomy-gloomy) intensifies the expression onu tih (day this). Similarly, banam-banam. Example (2) is also used to express a very gloomy day. However, $s a b-s a b$ and banam-banam cannot be used to describe a gloomy person. In Example (3), sorut-sorut is used to show a person who is very weak. Example (1) cannot stand on its own because it does have any semantic meaning but when it is used with other expressions, it intensifies the meaning of these expressions. Examples (2)-(4), however can stand alone and the reduplication of these words also intensifies the meaning.

\section{Types of intensifiers}

Paradis (2008) outlined five types of intensifiers according to the degree of boundedness: (1) maximizers, (2) approximators, (3) boosters, (4) moderators, and (5) diminishers. Figure 2 is a scale structure that shows the degree of intensity for these five types of intensifiers.

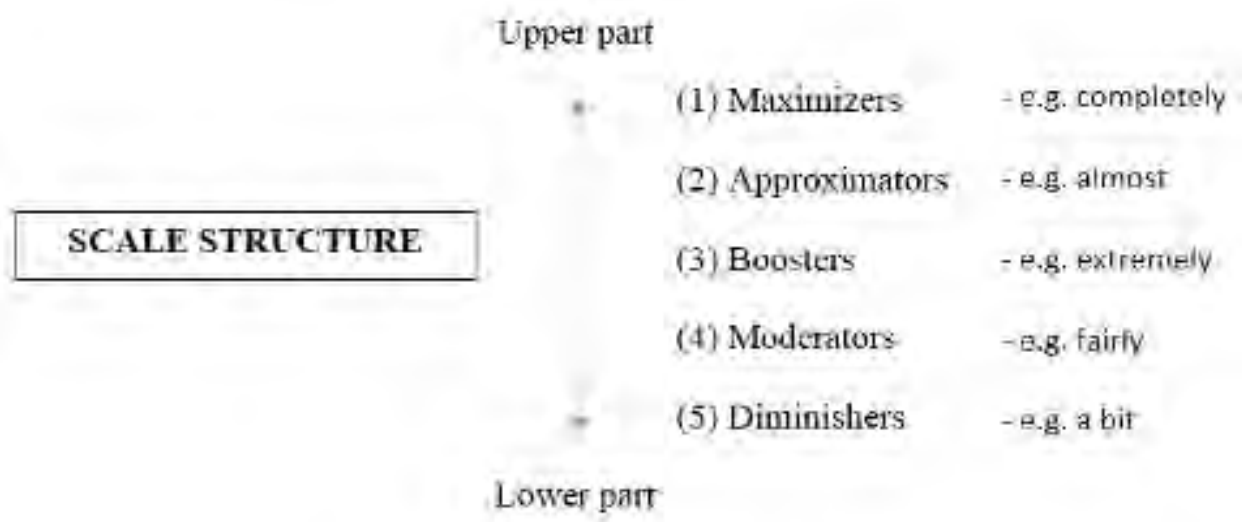

Figure 2. Scale structure by Paradis (2008)

In Bidayuh Bau-Jagoi, two out of five types of intensity are found: maximizers and boosters. Table 2 shows the degree of intensity for the intensifier $j a^{\prime} a t$ which in this context means "ugly".

Table 2

Intensity of Bidayuh Bau-Jagoi intensifiers based on Paradis' (2008) Scale Structure

\begin{tabular}{|l|l|l|l|}
\hline Bidayuh Bau-Jagoi & Literal translation & English & $\begin{array}{l}\text { Scale } \\
\text { Structure }\end{array}$ \\
\hline Yoh ja'at podak & He ugly utterly & He is utterly ugly & Maximizer \\
\hline Yoh tok-tok ja'at & He very, very ugly & He is very, very ugly & Booster \\
\hline $\begin{array}{l}\text { Yoh sikia ja'at / Yoh } \\
\text { ja'at manah/ Yoh } \\
\text { ja'at bonar }\end{array}$ & $\begin{array}{l}\text { He very ugly/ He very/ He ugly } \\
\text { very }\end{array}$ & He is very ugly & Booster \\
\hline Yoh ja'at & He ugly & He is ugly & \\
\hline
\end{tabular}

In Table 2, the intensity of ugliness increases from "ugly" (ja'at) to "extremely ugly" (ja'at podak). The word podak is a specific lexical item intensifier is

Intensifiers in Bidayuh Bau-Jagoi 
a maximizer. The intensifiers, sikia, manah, bonar and tok-tok, which show moderate intensity of ugliness are boosters.

\section{Maximizers.}

In English, examples of maximizers are "completely", "entirely", "fully", "perfectly", "thoroughly", "utterly", and "absolutely", as used in Harry Potter novels (Pintaric \& Frleta, 2014). The function of maximizers is to give maximum intensity to the meaning of the adjective. "Utterly" is chosen as the literal translation for the maximizers in Bidayuh Bau-Jagoi language. Maximizers in Bidayuh Bau-Jagoi come in the form of intensifiers in the category of specific lexical items.

Maximizers in Bidayuh Bau-Jagoi are meaningless on their own and need to be paired with a specific adjective. They are always placed after the adjective, for example, ja'at podak (ugly utterly) in Table 2. Example (5) depicts a meaningless maximizers tatam as it is not paired with any adjective. Example (6) shows the adjective bongam with maximum intensity when paired with tatam. Tatam here indirectly means "utterly", but on its own, it does not carry any semantic meaning. Native speakers do not say yoh bongam playuo although playuo also means "utterly" because in Bidayuh Bau-Jagoi maximizers must be paired with their respective adjectives as in the concept of lock and key.

$$
\begin{aligned}
& \text { Yoh } \\
& \text { He/she }
\end{aligned}
$$

(6)

$$
\text { Yoh }
$$

$\mathrm{He} / \mathrm{she}$

$\mathrm{He} / \mathrm{she}$ is utterly deaf. tatam.

*no meaning

$\begin{array}{ll}\text { bongam } & \text { tatam. } \\ \text { deaf } & \text { utterly. }\end{array}$

Although maximizers in Bidayuh are generally paired with certain adjectives, there are however, exceptions. Some adjectives can share two or more maximizers. Based on Example (7), ngakag can represent intensity specifically for the taste of pidie (salty) and poras (spicy).

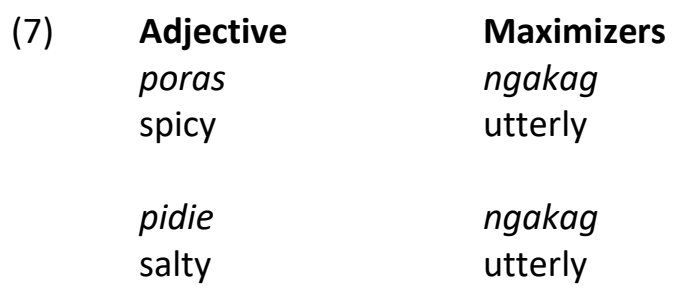

There is one maximizer in Bidayuh Bau-Jagoi which can be paired with 12 adjectives, based on the data collected and that is posah (see Table 3.). 
Table 3

Adjectives that shares the maximize "posah" in Bidayuh Bau-Jagoi language

\begin{tabular}{lll}
\hline Adjective & & Maximizers \\
\hline 1. tame & tatih & posah \\
2. wild & siga' & posah \\
3. bright & jawak & posah \\
4. dark & mopung & posah \\
5. short & kodo' & posah \\
6. tall & bigatung & posah \\
7.weak & lemah & posah \\
8. wrong & salah & Posah \\
9. narrow & sikitok & Posah \\
10. quick & patos & Posah \\
11. smelly & bu'uh & Posah \\
12. sharp & rojak & Posah \\
\hline
\end{tabular}

Interestingly, posah is attached to some antonym adjectives pairs as shown in items (1)-(6). However, not all domains have this pattern, only domain 1 Quality/Situation of tatih (tame) and siga (wild) have antonyms in the adjective pair. Items (3) and (4) belong to domain 2 which is colour. Items (5) and (6) belong to domain 3 , measurement. All of these adjective pairs show contrasting meaning but share the same maximizer, posah.

Appendix 1 shows the full list of 86 maximizers in Bidayuh Bau-Jagoi language which are used with 115 adjectives.

\section{Boosters.}

Pintaric and Frleta (2014) listed three most common boosters, with "very" being the most popular one followed by "really" and "so". Boosters identified from the data are sikia, manah and bonar, literally translated as "very".

The first characteristic of boosters in Bidayuh Bau-Jagoi is its position when paired with adjectives. Boosters can be placed before or after an adjective. Example (8) shows the only Booster in Bidayuh Bau-Jagoi which is positioned before an adjective. Sikia is equivalent to the English intensifier "very", which amplifies any adjectives that follows. Sikia can be paired with any adjective as shown in Examples (8) and (9).

(8)

Booster
Sikia
Very

(9)

Booster
sikia
very

\section{Adjective \\ isok \\ small}

\section{Adjective}

mopung

dark 
Examples (10) to (13) show the only two boosters in Bidayuh Bau-Jagoi which are positioned after an adjective, "manah" and "bonar". These two intensifiers can be used interchangeably with any adjective without losing their semantic function, which is to amplify an adjective.

(10)

Booster
isok
small

(11)

Booster
isok
small

(12)

Booster
mopung
dark

\section{Adjective manah very}

Adjective bonar very

\author{
Adjective \\ manah \\ very
}

\section{Adjective} bonar very

Based from the data collected, the second characteristic of boosters is the level of intensity it represents. The function of boosters is to amplify an adjective it is paired to, and the level of intensity is not quite as intense as a maximizer. The boosters "manah" and "bonar" in Examples (14) and (15) show how the boosters amplify the meaning of the adjectives that preceed them. Most of the Boosters in Bidayuh BauJagoi are free-formed intensifiers, meaning they can be paired with any adjective.

Paguh
Nice
Adj

Your rice is very nice.

$$
\begin{aligned}
& \text { Siga' } \\
& \text { Wild }
\end{aligned}
$$

That dog is very wild.

$\begin{array}{lll}\text { manah } & \text { podi } & \text { mu'. } \\ \text { very } & \text { rice } & \text { your. } \\ \text { Int } & \mathrm{N} & \mathrm{P}\end{array}$

bonar kosuong noh.

very dog that.

\section{Conclusion}

This study has investigated the categories and types of intensifiers in the Bidayuh Bau-Jagoi variety spoken by the Bidayuh living in Sarawak, Malaysia. In Bidayuh BauJagoi, intensifiers are categorised into lexical items and reduplication. Intensifiers that fall under lexical items are further divided into general and specific lexical items. For the general lexical intensifiers, there are three, which are sikia, manah and bonar and all three carry the meaning "very". These types of intensifiers are usually 
boosters which amplify the adjective it is paired with and the level of intensity is not quite as intense as a maximizer.

For the specific lexical intensifiers, they are paired only with specific adjectives. However, there is the exception for the intensifiers posah and ngakag which can be paired with different adjectives. These specific lexical intensifiers are placed after an adjective and are usually maximizers. Their function is to give maximum intensity to the meaning of the adjective. In Bidayuh Bau-Jagoi, there are only three general lexical intensifiers unlike English which has a huge range of intensifiers to choose from. However, Bidayuh Bau-Jagoi has a lot of specific lexical intensifiers and 86 has been identified in this study.

In Bidayuh Bau-Jagoi, there are only full reduplication forms of intensifiers and no partial reduplication. There are two types of full reduplication, the first being a reduplication of the word tok. Once reduplicated (tok tok), it carries the meaning of "very, very". The second type of full reduplication is where adjectives are reduplicated and intensify the meaning of the expressions that precede them. Only four reduplications of adjectives were found in the study which are banam-banam, sab-sab, sorut-sorut, and suom-suom. Intensifiers in Bidayuh Bau-Jagoi are usually placed after the adjective with the exception of sikia.

The Indonesian dialect, Banyumas, is similar to Bidayuh Bau-Jagoi in terms of the existence of lexical items and reduplications as intensifiers. This is because both languages belong to the same language family, which is the Austronesian, MalayoPolynesian (Simons \& Fennig, 2018). These specific lexical intensifiers are unique in that they have to be paired with the correct adjectives and they are less frequently used compared to general lexical intensifiers. The incorrect usage and combination of intensifiers and adjectives would result in the disruption of the meaning of the intended expression. Besides that, since the use of intensifiers are to strengthen the meaning of the adjectives and to show emphasis and intensity, dropping them would decrease such effect.

As shown in this paper, special lexical intensifiers need to be paired with the correct adjectives, thus, these intensifiers may not be passed on to the next generation since they are more difficult to learn for the younger generation and new speakers of Bau-Jagoi. Further research in the area can be in form of a corpus study to compare the use of intensifiers in the different Bidayuhs dialects and to find out if there are generational differences on the use of intensifiers among Bidayuhs. These findings would allow comparative studies between either the Bidayuh dialects or other languages.

\section{References}

Ahmad, Z., \& Jalaluddin, N. H. (2012). Incorporating structural diversity in the Malay grammar. Journal of Language Studies, 12(1), 17-34.

Bantawig, R. B., \& Marano, F. B. (2017). Morphological features of SiquijodnonCebuano language. Pertanika Journal of Social Sciences and Humanities, 25(3), 1139-1166.

Bickel, B., Comrie, B., \& Haspelmath, M. (2015). The Leipzig Glossing Rules. Conventions for interlinear morpheme by morpheme glosses. Revised version 
of 2002. Retrieved from https://www.eva.mpg.de/lingua/pdf/GlossingRules.pdf

Bolinger, D. (1972). Degree words. The Hague, Paris: Mounton.

Bongarrá, M., \& Tan, G. (2017). Some characteristics of Bidayuh adjectives. In M. Bongarrá, J. Arritt, \& F. G. Kayad (Eds.), Selected Papers of the Bidayuh Language Development and Preservation Project: 2003-2017 (107-134). Dayak Bidayuh National Association, Kuching, Malaysia.

Chang, P. F. (2002). History of Bidayuh in Kuching Division. Kuching, Malaysia: Lee Ming Press.

Dayak Bidayuh National Association. (2013). Buk Bang Sinda: Bidayuh Bau-EnglishMalay, Bidayuh Bau Wordlist. Kuching, Malaysia: DBNA.

Fries, C. C. (1940). American English grammar. New York, NY: Appleton Century Crofts.

Hadiati, C. (2017). The realization of intensifiers in Banyumas dialect. Journal of Language Teaching and Research, 8(5), 940-947

Holmes, J. (2006). An introduction to sociolinguistics. London, UK: Pearson Education Limited.

Karim, N. K., Onn, F. M., Musa, H., \& Mahmood, A. H. (2010). Tatabahasa dewan. Edisi Ketiga. Amapng, Malaysia: Dawama Sdn.Bhd.

Kluge, A. (2017). A grammar of Papuan Malay. Berlin, Germany: Language Science Press.

Nadarajan, S. (2006). A crosslinguistic study of reduplication. The Arizona Working Papers in Second Language Acquisition and Teaching, 13, 39-53.

Paradis, C. (2008). Configurations, construal and change: Expressions of degree. English Language and Linguistics, 12(2), 317-343.

Pintarić, A.P., \& Frleta, Z. (2014). Upwards intensifiers in the English, German and Croatian Language. Journal for Foreign Languages, 6(1), 31-48.

Quirk, R., Greenbaum, S., Leech, G., \& Svartvik, J. (1985). A comprehensive grammar of the English language. London, UK: Longman.

Rensch, C. R., Rensch, C. M., Noeb, J., \& Ridu, R. S. (2012). The Bidayuh language yesterday, today and tomorrow. SIL International [online]. https://www.sil.org/system/files/reapdata/14/22/41/1422417912486582748 40881242401680083100/ebook_33_Bidayuh_6_21_12_rev.pdf

Simons, G.F., \& Fennig, C. D., (eds.). (2018). Ethnologue: Languages of the World, Twenty-first edition. SIL International: Dallas, Texas. Retrieved from: http://www.ethnologue.com.

Stewart, T. W., \& Vaillette, N. (2001). Language file: Material for an Introduction to language and linguistics ( $8^{\text {th }}$ ed). Ohio: Ohio State University Press.

Stoffel, C. (Ed., 1901). Intensives and down-toners. Heidelberg, Germany: C. Winter.

Su, Y. (2016). Corpus-based comparative study of intensifiers: Quite, pretty, rather and fairly. Journal of World Languages, 3(3), 224-236.

Wittouck, H., 2011. A Corpus-based study on the rise and grammaticalisation of intensifiers in British and American English (Unpublished Master's Thesis). Faculty of Arts and Philosophy, Ghent, Belgium. 
Appendix 1: List of Ajdectives and Intensifiers

\begin{tabular}{|c|c|c|c|c|c|}
\hline \multirow[b]{2}{*}{ Domains } & & \multirow[b]{2}{*}{$\begin{array}{c}\text { Adjectives } \\
\text { (Bidayuh/English) }\end{array}$} & \multicolumn{3}{|c|}{ Intensifiers } \\
\hline & & & $\begin{array}{c}\text { Boosters (general } \\
\text { lexical items) }\end{array}$ & $\begin{array}{c}\text { Booster (Full } \\
\text { Reduplication) }\end{array}$ & $\begin{array}{c}\text { Maximizers } \\
\text { (Specific general } \\
\text { items) }\end{array}$ \\
\hline \multirow[t]{18}{*}{$\begin{array}{l}\text { Quality / } \\
\text { Situation }\end{array}$} & 1. & Paguh-good & $\begin{array}{l}\text { sikia paguh } \\
\text { paguh manah } \\
\text { paguh bonar }\end{array}$ & - & - \\
\hline & 2. & $J a^{\prime} a t$ - Bad/ugly & $\begin{array}{l}\text { sikia ja'at } \\
\text { ja'at manah } \\
\text { ja'at bonar }\end{array}$ & - & ja'at podak \\
\hline & 3. & Romah-weak & $\begin{array}{l}\text { sikia romah } \\
\text { romah manah } \\
\text { romah bonar }\end{array}$ & - & romah posah \\
\hline & 4. & Bigaut - hastily & $\begin{array}{l}\text { sikia bigaut } \\
\text { bigaut manah } \\
\text { bigaut bonar }\end{array}$ & - & bigaut biguak \\
\hline & 5. & Gogah - healthy & $\begin{array}{l}\text { sikia gogah } \\
\text { gogah manah } \\
\text { gogah bonar }\end{array}$ & - & gogah girinas \\
\hline & 6. & Ponai - clever & $\begin{array}{l}\text { sikia ponai } \\
\text { ponai manah } \\
\text { ponai bonar }\end{array}$ & - & bijak sirodik \\
\hline & 7. & Buduo-stupid & $\begin{array}{l}\text { sikia buduo } \\
\text { buduo manah } \\
\text { buduo bonar }\end{array}$ & - & buduo playuo \\
\hline & 8. & Brani - brave & $\begin{array}{l}\text { sikia brani } \\
\text { brani manah } \\
\text { brani bonar }\end{array}$ & - & $\begin{array}{l}\text { brani pogan } \\
\text { pogan brani }\end{array}$ \\
\hline & 9. & Toru - scared & $\begin{array}{l}\text { sikia toru } \\
\text { toru manah } \\
\text { toru bonar }\end{array}$ & - & toru sikubuon \\
\hline & 10 & Samuh - arrogant & $\begin{array}{l}\text { sikia samuh } \\
\text { samuh manah } \\
\text { samuh bonar }\end{array}$ & - & samuh blawa \\
\hline & 11. & $\begin{array}{l}\text { Gogah } \\
\text { hardworking }\end{array}$ & $\begin{array}{l}\text { sikia gogah } \\
\text { gogah manah } \\
\text { gogah bonar }\end{array}$ & - & - \\
\hline & 12 & Maras - lazy & $\begin{array}{l}\text { sikia maras } \\
\text { maras manah } \\
\text { maras bonar }\end{array}$ & - & maras masar \\
\hline & 13. & Siroro - funny & $\begin{array}{l}\text { sikia siroro } \\
\text { siroro manah } \\
\text { siroro bonar }\end{array}$ & - & - \\
\hline & 14 & Bongam - deaf & $\begin{array}{l}\text { sikia bongam } \\
\text { bongam manah } \\
\text { bongam bonar }\end{array}$ & - & bongam tatam \\
\hline & 15 & Gomu' - fat & $\begin{array}{l}\text { sikia gomu' } \\
\text { gomu' manah } \\
\text { gomu' bonar }\end{array}$ & - & Gomu' tutuk \\
\hline & 16 & Mayuh - thin & $\begin{array}{l}\text { sikia mayuh } \\
\text { mayuh manah } \\
\text { mayuh bonar }\end{array}$ & - & mayuh rikag \\
\hline & 17 & Bauh - new & $\begin{array}{l}\text { sikia bauh } \\
\text { bauh manah } \\
\text { bauh bonar }\end{array}$ & - & bauh tibo'on \\
\hline & 18 & oma - old & $\begin{array}{l}\text { sikia oma } \\
\text { oma manah } \\
\text { oma bonar }\end{array}$ & - & oma raya \\
\hline
\end{tabular}

Intensifiers in Bidayuh Bau-Jagoi 




Intensifiers in Bidayuh Bau-Jagoi 


\begin{tabular}{|c|c|c|c|c|c|}
\hline \multirow[t]{8}{*}{ Colours } & 40 & Birieh -red & $\begin{array}{l}\text { sikia birieh } \\
\text { birieh manah } \\
\text { birieh bonar }\end{array}$ & - & birieh pa'ang \\
\hline & 41 & Biru-blue & $\begin{array}{l}\text { sikia biru } \\
\text { biru manah } \\
\text { biru bonar }\end{array}$ & - & biru kodu \\
\hline & 42 & Mopu' -white & $\begin{array}{l}\text { sikia mopuk } \\
\text { mopuk manah } \\
\text { mopuk bonar }\end{array}$ & - & mopuk suik \\
\hline & 43. & Songot -black & $\begin{array}{l}\text { sikia songot } \\
\text { songot manah } \\
\text { songot bonar }\end{array}$ & - & songot potok \\
\hline & 44 & Sia'- yellow & $\begin{array}{l}\text { sikia siak } \\
\text { siak mana } \\
\text { siak bonar }\end{array}$ & - & siak pogah \\
\hline & 45 & bleak & - & $\begin{array}{l}\text { Banam-banam } \\
\text { sab-sab }\end{array}$ & - \\
\hline & 46 & Jawa' -bright & $\begin{array}{l}\text { sikia jawak } \\
\text { jawak manah } \\
\text { jawak bonar }\end{array}$ & - & $\begin{array}{l}\text { jawak posah } \\
\text { jawak kidadak }\end{array}$ \\
\hline & 47 & Mopung -dark & $\begin{array}{l}\text { sikia mopung } \\
\text { mopung manah } \\
\text { mopung bonar }\end{array}$ & - & $\begin{array}{l}\text { mopung pipiet } \\
\text { mopung posah }\end{array}$ \\
\hline \multirow[t]{12}{*}{ Measurement } & 48 & Omu- long & $\begin{array}{l}\text { sikia omu } \\
\text { omu manah } \\
\text { omu bonar }\end{array}$ & - & omu bonar \\
\hline & 49 & Kodok-short & $\begin{array}{l}\text { sikia kodok } \\
\text { kodok manah } \\
\text { kodok bonar }\end{array}$ & - & $\begin{array}{l}\text { kodok posah } \\
\text { kodit titit }\end{array}$ \\
\hline & 50 & Ayuh-big & $\begin{array}{l}\text { sikia ayuh } \\
\text { ayuh manah } \\
\text { ayuh bonar }\end{array}$ & - & - \\
\hline & 51 & Isok-small & $\begin{array}{l}\text { sikia isok } \\
\text { isok manah } \\
\text { isok bonar }\end{array}$ & - & - \\
\hline & 52 & Tobar-thick & $\begin{array}{l}\text { sikia tobar } \\
\text { tobar manah } \\
\text { tobar bonar }\end{array}$ & - & $\begin{array}{l}\text { tobar lalar } \\
\text { tobar mongang }\end{array}$ \\
\hline & 53. & Ridie'- thin & $\begin{array}{l}\text { sikia ridie' } \\
\text { ridie' manah } \\
\text { ridie' bonar }\end{array}$ & - & ridie' ngira'ing \\
\hline & 54 & Bigatung-tall & $\begin{array}{l}\text { sikia bigatung } \\
\text { bigatung manah } \\
\text { bigatung bonar }\end{array}$ & - & bigatung posah \\
\hline & 55 & Rapat-short & $\begin{array}{l}\text { sikia rapat } \\
\text { rapat manah } \\
\text { rapat bonar }\end{array}$ & - & rapat didat \\
\hline & 56 & Sikito'-narrow & $\begin{array}{l}\text { sikia sikito' } \\
\text { sikito' manah } \\
\text { sikito' bonar }\end{array}$ & - & Sikito' posah \\
\hline & 57 & Towas -wide & $\begin{array}{l}\text { sikia towas } \\
\text { towas manah } \\
\text { towas bonar }\end{array}$ & - & towas mosuong \\
\hline & 58 & $B a^{\prime} a t$ - heavy & $\begin{array}{l}\text { sikia ba'at } \\
\text { ba'at manah } \\
\text { ba'at bonar }\end{array}$ & - & ba'at tatak \\
\hline & 59 & Jangan -light & $\begin{array}{l}\text { sikia jangan } \\
\text { jangan manah } \\
\text { jangan bonar }\end{array}$ & - & $\begin{array}{l}\text { jangan atieng } \\
\text { jangan kedanan }\end{array}$ \\
\hline Shape & 60 & Borong-round & $\begin{array}{l}\text { sikia borong } \\
\text { borong manah } \\
\text { borong bonar }\end{array}$ & - & $\begin{array}{l}\text { bulat tatar } \\
\text { borong totong }\end{array}$ \\
\hline
\end{tabular}

Intensifiers in Bidayuh Bau-Jagoi 




Intensifiers in Bidayuh Bau-Jagoi 


\begin{tabular}{|c|c|c|c|c|c|}
\hline & & & suka bonar & & \\
\hline & 82 & Rami- happy & $\begin{array}{l}\text { sikia rami } \\
\text { rami manah } \\
\text { rami bonar }\end{array}$ & - & rami munuos \\
\hline & 83. & Awoh -sad & $\begin{array}{l}\text { sikia awoh } \\
\text { awoh manah } \\
\text { awoh bonar }\end{array}$ & - & - \\
\hline & 84 & Gaus- fierce & $\begin{array}{l}\text { sikia gaus } \\
\text { gaus manah } \\
\text { gaus bonar }\end{array}$ & - & $\begin{array}{l}\text { gaus bekeng } \\
\text { gaus bunying }\end{array}$ \\
\hline \multirow[t]{6}{*}{ Sensory - Taste } & 85 & Sidi'-delicious & $\begin{array}{l}\text { sikia sidi' } \\
\text { sidi' manah } \\
\text { sidi' bonar }\end{array}$ & - & sidi' bromak \\
\hline & 86 & Pidie' -salty & $\begin{array}{l}\text { sikia pidie' } \\
\text { pidie' manah }^{\prime} \\
\text { pidie' bonar }\end{array}$ & - & pidie' ngakag \\
\hline & 87 & Po'it -bitter & $\begin{array}{l}\text { sikia po'it } \\
\text { po'it manah } \\
\text { po'it bonar }\end{array}$ & - & po'it podiel \\
\hline & 88 & Masuom-sour & $\begin{array}{l}\text { sikia masuom } \\
\text { masuom manah } \\
\text { masuom bonar }\end{array}$ & - & masuom kiduduom \\
\hline & 89 & Poras-spicy & $\begin{array}{l}\text { sikia poras } \\
\text { poras manah } \\
\text { poras bonar }\end{array}$ & - & poras ngakag \\
\hline & 90 & Bidiem- bland & $\begin{array}{l}\text { sikia bidiem } \\
\text { bidiem manah } \\
\text { bidiem bonar }\end{array}$ & - & $\begin{array}{l}\text { bidiem playuo } \\
\text { bidiem titieb }\end{array}$ \\
\hline \multirow[t]{6}{*}{ Sensory- Sight } & 91. & Sangon- beautiful & $\begin{array}{l}\text { sikia sangon } \\
\text { sangon manah } \\
\text { sangon bonar }\end{array}$ & - & sangon poson \\
\hline & 92 & Gap-handsome & $\begin{array}{l}\text { sikia gap } \\
\text { gap manah } \\
\text { gap bonar }\end{array}$ & - & - \\
\hline & 93. & Payuh -cute & $\begin{array}{l}\text { sikia payuh } \\
\text { payuh manah } \\
\text { payuh bonar }\end{array}$ & - & - \\
\hline & 94 & Moduok-ugly & $\begin{array}{l}\text { sikia moduok } \\
\text { moduok manah } \\
\text { moduok bonar }\end{array}$ & - & moduok tutuok \\
\hline & 95 & Kois- dirty & $\begin{array}{l}\text { sikia kois } \\
\text { kois manah } \\
\text { kois bonar }\end{array}$ & - & $\begin{array}{l}\text { ko'is kobos } \\
\text { kois kodier }\end{array}$ \\
\hline & 96. & Bisig-clean & $\begin{array}{l}\text { sikia bisig } \\
\text { bisig manah } \\
\text { bisig bonar }\end{array}$ & - & bisig korig \\
\hline \multirow[t]{4}{*}{$\begin{array}{l}\text { Sensory- } \\
\text { Hearing }\end{array}$} & 97. & Dowo -hoarse & $\begin{array}{l}\text { sikia dowo } \\
\text { dowo manah } \\
\text { dowo bonar }\end{array}$ & - & - \\
\hline & 98. & Motug-quiet & $\begin{array}{l}\text { Sikia motug } \\
\text { Motug manah } \\
\text { Motug bonar }\end{array}$ & otug-otug & \\
\hline & 99. & Bidaruog -noisy & $\begin{array}{l}\text { sikia bidaruog } \\
\text { bidaruog manah } \\
\text { bidaruog bonar }\end{array}$ & & bidaruog bido'ong \\
\hline & 10 & Kibuk -Small voice & $\begin{array}{l}\text { sikia kibuk } \\
\text { kibuk manah } \\
\text { kibuk bonar }\end{array}$ & - & - \\
\hline \multirow[t]{2}{*}{ Sensory - smell } & 10 & Wangi -fragrant & $\begin{array}{l}\text { sikia wangi } \\
\text { wangi manah } \\
\text { wangi bonar }\end{array}$ & - & - \\
\hline & 10 & $B u^{\prime} u h$ - stench & sikia bu'uh & - & bu'uh posah \\
\hline
\end{tabular}

Intensifiers in Bidayuh Bau-Jagoi 




